$\begin{gathered}\text { ART LIBR ARIES JOURNAL } \\ \text { Revue de Bibliothèques d'Art } \\ \text { Zeitschrift für Kunstbibliotheken } \\ \text { Revista de Bibliotecas de Arte }\end{gathered}$
$\begin{gathered}\text { Architecture for all: } \\ \text { combining drawings collections in London }\end{gathered}$
$\frac{\text { Architecture libraries in Catalonia }}{\text { Architecture librarians get together }}$
$\frac{\text { Making trade literature and museum ephemera }}{\text { more accessible }}$
Artists in Canada

VOLUME 26

NUMBER 2

$\begin{array}{llll}2 & 0 & 0 & 1\end{array}$ 


\section{ARThibliographies modern}

\section{NOW PUBLISHED BY CSA}

\section{Your reference source for modern and contemporary art}

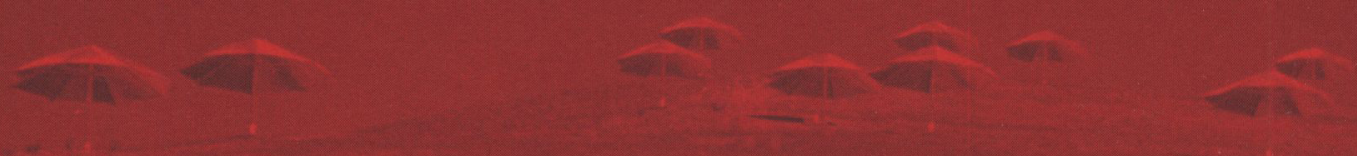

"...useful for both the beginning and experienced researcher,

$A B M$ on the Web is an essential tool for large public, special, academic, and research libraries." - Library Journal, February 2000

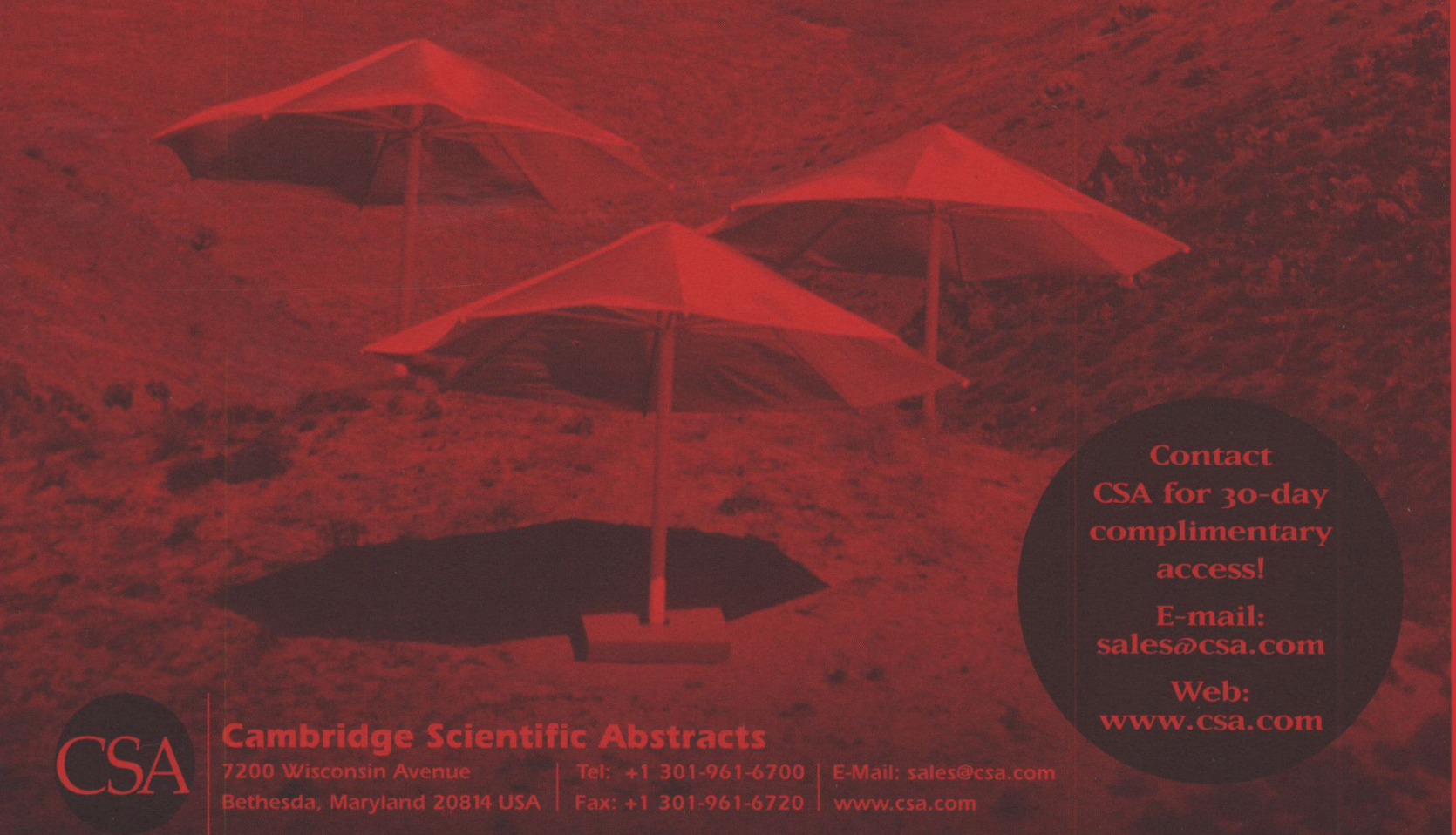




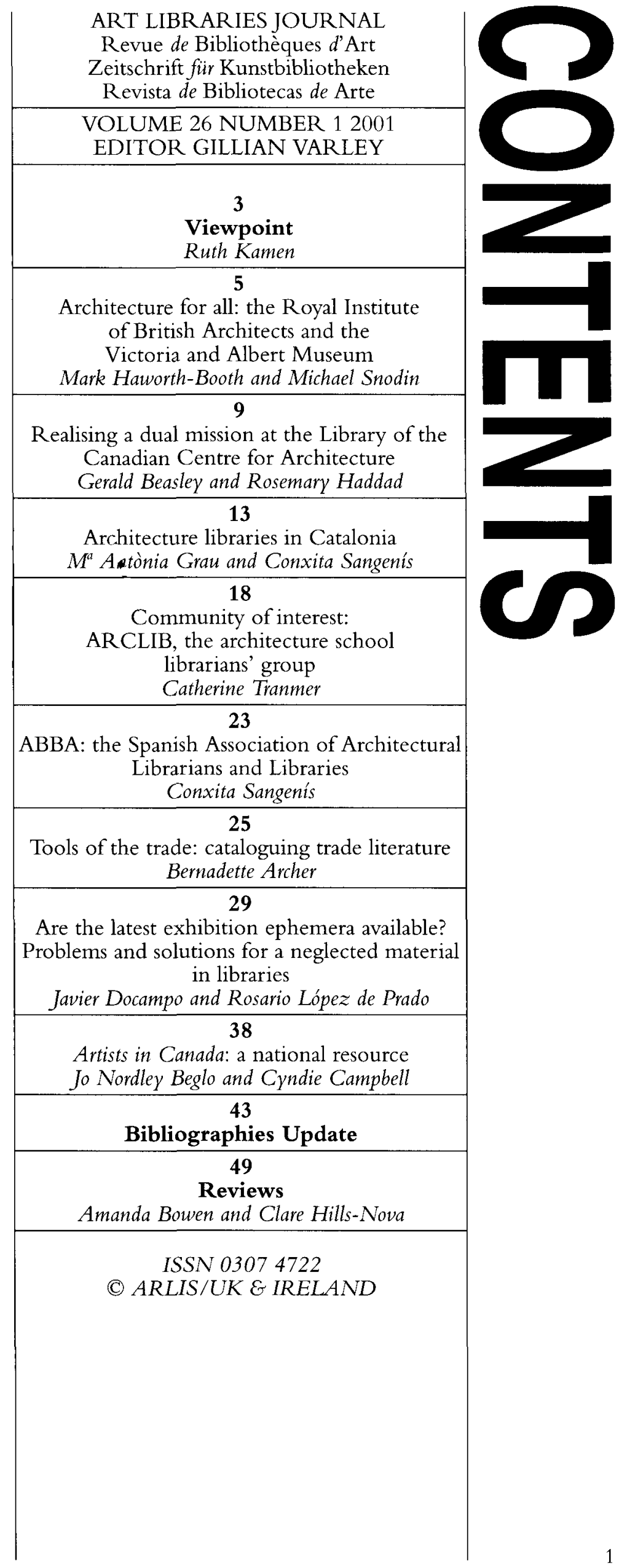


ART LIBRARIES JOURNAL

Revue de Bibliotheques d'Art

Zeitschrift für Kunstbibliotheken

Revista de Bibliotecas de Arte

\section{Editor}

Gillian Varley

28 Fieldend

Twickenham TW1 4TF

UK

Tel: +44(0)20 88925318

Fax: +44 (0)2088924712

Email: g.varley@arlis2.demon.co.uk

\section{Deputy Editor}

Peter Trepanier

Library

National Gallery of Canada

380 Sussex Drive

P.O.Box 427 Station A

Ottawa, Ontario K1N 9N4

Canada

Tel: +1 6139900587

Fax: +16139909818

Email: ptrepani@gallery.ca

\section{Reviews Editor}

Sheila Klos

Head Librarian

Dumbarton Oaks

1703 32nd Street, NW

Washington, DC 20007-2961

USA

Tel: +1 2023396998

Fax: +1 2023331806

Email: Klos\$@doaks.org

Items for review should be sent to the Reviews Editor's address
The Art Libraries Journal is published by ARLIS/UK \& Ireland for the international art library community and also for all who are interested in the documentation of the visual arts. It highlights the rapid changes in information technology which are affecting the activities of the profession, and documents developments in the converging fields of libraries, museums, archives and visual resources. At the same time it is a journal rooted in the traditional concerns of art librarians.

The majority of the $A L J$ s articles are specially commissioned, but relevant conference papers are also published, including selected contributions to the annual meetings of the IFLA Section of Art Libraries. In addition, the Section of Art Libraries Newsletter is currently distributed gratis to Art Libraries Joumal subscribers. Contributions and correspondence are invited and should be submitted to the Editor.

Regular features include:

- reviews of bibliographies and core reference works within the broad area of the visual arts, and of books about, or relevant to, art librarianship

- an annual Bibliographies Update providing current awareness of art bibliographies of all kinds, including bibliographical databases

- the Annual Bibliography of Art Librarianship, which records significant writings on art librarianship, wherever and in whatever language they appear

- an annual index to the contents.

The $A L J$ publishes material in English, French, German and Spanish; articles in languages other than English are accompanied by an English summary.

The $A L J$ appears quarterly, and goes to libraries and individuals in over 45 countries.

The Art Libraries Journal is available worldwide with membership of ARLIS/UK \& Ireland and costs $£ 38$ for individuals (within the UK and Ireland only); for institutions it is $£ 57 / \$ 114$ (surface mail) or $\delta 67 / \$ 134$ (airmail). Non-members outside the UK and Ireland can subscribe to the

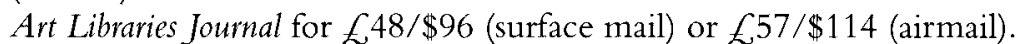

Single copies may be purchased at $£ 12 / \$ 24$ each $(£ 11 / \$ 22$ to ARLIS/UK \& Ireland members), surface mail postage included.

A limited number of complimentary subscriptions to the Art Libraries Journal is available, for periods of up to two years, to libraries which because of currency problems or other difficulties are genuinely unable to subscribe in the normal way. Applicants are invited to write to the Editor in the first instance.

Membership, subscription and advertising enquiries should be sent to Sonia French, Administrator ARLIS/UK \& Ireland 18 College Road

Bromsgrove, Worcs. B60 2NE, UK

(Tel/fax: +44 (0)1527 579298; email sfrench@arlis.demon.co.uk) 